\title{
The use of recycled plastic in concrete. An alternative to reduce the ecological footprint
}

\section{Uso del plástico reciclado en el hormigón. Una alternativa para reducir la huella ecológica}

Iris Sanchez Soloaga (Main Author)

CINTEMAC. Universidad Tecnológica Nacional. Facultad Regional

Córdoba. Argentina.

Maestro M. López esq. Cruz Roja Argentina - Ciudad Universitaria, Córdoba, Argentina

Tel: +54-0351-598-6000 / 598-6001.

cintemac@gmail.com

Angel Oshiro (Contact Author)

CINTEMAC. Universidad Tecnológica Nacional. Facultad Regional

Córdoba. Argentina.

cintemac@gmail.com

\section{Resumen}

El Hormigón en su producción emite gases a la atmósfera generando un impacto ambiental, sin embargo la reducción de su consumo no debería ser la mejor alternativa a esta problemática ya que podría afectar el desarrollo económico de una región o país, la solución está en el diseño sostenible del material. La Huella Ecológica (HE) permite estimar el consumo de recursos y asimilación de desechos de una determinada población, expresados en área de suelo productivo. Este trabajo presenta el cálculo de la HE de un hormigón situado en Córdoba-Argentina; se estima la superficie necesaria para satisfacer los consumos asociados a los materiales utilizados en el hormigón con incorporación de plástico como reemplazo del agregado grueso, procurando contribuir al cuidado del ambiente. Concluyendo, si bien los agregados ocupan el mayor volumen en la elaboración del hormigón, tienen una carga ambiental pequeña en proporción a la HE de la totalidad de los materiales utilizados, afectando sólo el $8 \%$. Esto se debe a que las tasas de liberación de $\mathrm{CO}_{2}$ más significativas en la huella total del hormigón corresponden principalmente al contenido de cemento. No obstante el uso de residuos plásticos en el hormigón, aporta beneficios ambientales.

Palabras clave: Reciclado, plástico, hormigón, ecológico, huella.

\section{Introduction}

The ecological footprint is an indicator defined as "the area of ecologically productive land (cultivates, grass, woods or water ecosystems) necessary to produce the used resources and to assimilate the residues generated by a given population with a specific way of living with an unspecific way. (Wackernagel y Rees, 2001). Its main objective is to evaluate the impact on the planet of a certain way of life and to compare it with the bio capacity of the planet. Thus; it is a key indicator of sustainability.
Maria Positieri

CINTEMAC. Universidad Tecnológica Nacional. Facultad Regional Córdoba. Argentina.

cintemac@gmail.com

\author{
Manuscript Code: 0543 \\ Date of reception/acceptation: 01aug2014/01dec2014
}

\begin{abstract}
The concrete in its production emits gases into the atmosphere causing an environmental impact, however reducing their consumption should not be the best approach to this problem as it could affect the economic development of a region or country. The solution is in the design sustainable material. The Ecological Footprint (EF) to estimate the resource consumption and waste assimilation of a given population, expressed in area of productive land. This paper presents the calculation of a concrete EF located in CórdobaArgentina, the area required to meet the estimated consumption associated with the materials used in the concrete with incorporation of plastics as a replacement of coarse aggregate, as a contribution to protecting the environment. To conclude, the aggregates occupying the largest volume in the preparation of concrete have a small environmental load in proportion to the EF of all the materials used, affecting only $8 \%$. This is because the release rates of $\mathrm{CO}_{2}$ in the most significant overall footprint are mainly concrete cement content. However, the use of plastic waste in the concrete, will provide environmental benefits.
\end{abstract}

Keywords: Recycled, plastic, concrete, ecological, footprint.

The calculation of the ecological footprint is complex and sometimes impossible, that is the reason why this fact is its main limitation as an indicator. Basically its results are based on the observation of the following aspects: the amount of hectares used to urbanize, to generate infrastructures and working places; the necessary hectares to give vegetable food necessary; the surface needed for grass to feed the cattle; the marine surface necessary to produce fish; the hectares of wood necessary to counteract the generation of $\mathrm{CO}_{2}$ that causes our energetic consumption, among others. 
In this sense it will not only have an impact on the degree of the energetic efficiency reached in the processes but also on the employed source: more use of renewable energies, more ecological footprints. According to Juan Luis Doménech (2007) in our world, each person has at his disposal the resources produced by two hectares a year, distributed in the following way: 0.25 hectares of cultivation, 0.6 hectares of grass, 0.6 hectares of woods, 0.03 hectares of built lot and 0.5 hectares of sea. If we deduct the $12 \%$ needed for biodiversity, we will obtain 1.7 hectares/ cap/ year.

The world ecological footprint has grown $50 \%$ since 1970 till today. This is because of the growing in the electric energy consumption necessary to produce goods and services. The ecological footprint is at present, with the levels of present in the population of 2.3 hectares/ cap/ year, so that in the final balance a deficit of 0.6 hectares is obtained, that is to say, we have surpassed the capacity of global load in $30 \%$ at the minimum and as a consequence we are living above our possibilities Domenech (2007). It is important to point out that all these data are subject to a great uncertainty, with a variation within authors.

\section{Description of the problem}

The reinforced concrete is the most used material in the world, and after water, it is the most consumed product in the planet. Every year the reinforced concrete industry uses 1.6 billion of tons of concrete, 10 billions of tons of rocks and sand and a billion of water. Domenech (2007). We have to emphasize that for every ton of concrete, 1.5 tons of limestone and a high consumption of fossil fuel are necessary. The great popularity of concrete is due to its excellent characteristics, such as its great durability, resistance, etc. However, its use implies high environmental expenses, showing particularly, a high quantity of energy consumed and $\mathrm{CO}_{2}$ released during its elaboration.

In this section we will refer to the extent the environmental impact contributes to each of the main components of the concrete and the processes involved, taking into account Meg Calkings' book “Material for Sustainable Sites”, Calkins (2008).

1. Gases released to the atmosphere during the manufacture of concrete: nitrogen oxides $\left(\mathrm{NO}_{2}\right)$, sulfur dioxide $\left(\mathrm{SO}_{2}\right)$

2. Consumption of water: in the manufacture of concrete a great consumption of water is required; this is used to control the exhaustion of powder to the air, to cool the outgoing gases from the kiln, to cool the product and so on.

3. Consumption of the aggregates: the coarse and fine aggregates are supposed to be between $60 \%$ and $75 \%$ of the total volume inside the concrete. These can come from a mine or have been manufactures in a crushing of stones. The main impacts that these activities involve are: they usually alter the habitats of the plants and animals, leading to soil erosion and to air and water pollution, the processing of the materials such as silica, exhausts particles in the air that can cause irritations in the eyes and in the human respiratory system; finally, it is usually necessary to have a heavy machinery that can perform these tasks. This implies an important consumption of oil that releases $\mathrm{CO}_{2}$ into the atmosphere.

4. Transportation of the concrete: as regards transport, it is obvious that the most important environmental factors are the emission of $\mathrm{CO}_{2}$. Fortunately, at present, there are a high number of concrete factories and even elaboration plants dealing with very important works.

5. Emissions of carbon dioxide $\left(\mathrm{CO}_{2}\right)$ : the concrete industry produces about $5 \%$ of the total emissions of $\mathrm{CO}_{2}$, according to the data of emission available in Oficemen (group of manufacturers of concrete of Spain). The $60 \%$ comes from the decarbonation process (transformation of calcareous into lime) and about $30 \%$ or $40 \%$ of the oil are necessary for the process.

On the other hand, the growing of the industry of plastic in the world has been huge, from a little more than 3 million of tons in 1955 to 30 million of tons in 1977 (Jain et al., 1977). This figure reached 100 million of tons in 2001 (www.wasteonline.org.uk). Its intensive usage has caused a problem of waste very difficult to manage because it has the disadvantage that they are not degradable, that is why they are responsible for the polluting waste that accumulates in nature. The management of the solid waste is one of the main environmental problems in the world. With shortage of space in the dumping site to dispose of it and due to the costs every time more expensive, the addition of solid waste materials has become an attractive alternative for its final disposal.

\section{State of the Art}

The ecological footprint analysis has been applied to different levels, from a global scale (Wackemagel and Reers, 2001) to a home level (Chambers et al, 2000) Simmons et. al. (2000) calculated the first series of algorithms capable of converting "Use of Resources" to an "Area of Equivalent Hearth", titled "Eco Index Methodology" (Chambers et al, 2000). The Environmental Institute of Stockholm also adopted this pioneer approach. In the Polytechnic Center of Curitiba (Freitas et al, 2010) they studied the importance of the concrete in the generation of $\mathrm{CO}_{2}$ for a building site that is built. Some data were taken into account for the study, such as the elimination of $\mathrm{CO}_{2}$ that is generated in the process of obtaining the most important raw materials for the building, such as Portland cement, lime, bricks and ceramic tiles, steel and aluminum. Also professors of the Faculty of Civil Engineering, University of Positivo (Aline et al., 2011) studied the analysis of the life cycle of the concrete with the objective of verifying the environmental impact of the product. The materials that were checked are: natural sand, artificial sand, gravel and Portland cement, CP-IV- 32. The data were taken from the enterprises located in Curitiva and the Metropolitan area. For this analysis, the lineaments of the standard norms NBR 14.040:2009 were followed.

Currently, at a worldwide level, people are working in different paths of investigation to improve the calculation of the ecological footprint. This has been more and more representative and it has a lower error percentage. Thus, it is important to point out Juan Luis Doménech's job in the 
development of the Methodogy MC3, to be applicable to the calculation of the corporative ecological footprint, based in the accounting of the enterprise. This was the method applied to the present study, to a particular consumption of concrete in the province of Córdoba, Argentina and at a worldwide level, as a first approximation to a complex topic, whose solution requires a more extensive work.

As our own antecedent we can mention the work "The Calculation of the EF of concrete" that was presented in the V International Congress by AACT (Argentinian Association of Concrete Technology). For the calculation of the consumption of concrete by each Cordobensis, it was taken as reference the consumption of cement per capita, $378 \mathrm{~kg}$, as average seven and a half sacks, as was expressed by the Minister of Industry Debora Giorgi in "La Mañana de Córdoba" (2011) With a dosage for a conventional concrete and starting from the datum of 378 $\mathrm{kg}$ of cement per inhabitant, it is estimated that each Cordobensis consumes $2836 \mathrm{~kg}$ per year, as is presented in Table 1.

With the above mentioned data, it was obtained the consumption of energy, raw materials and release that are generated in the making of concrete and that are presented in Table 2. This table was made from a study by Häkkinene and Vares (1998) that shows the environmental profile of a concrete and establishes a guide about the proportion between the quantities involved in a material and in another one. The environmental impact that generates the consumption of coarse and fine aggregates are pointed out. The importance of this type of energy that is used for its manufacture is also pointed out.

\begin{tabular}{|c|c|c|c|c|}
\hline & Cement & Water & $\begin{array}{l}\text { Fine } \\
\text { aggregate } \\
\text { (sss) }\end{array}$ & $\begin{array}{l}\text { Coarse } \\
\text { aggregate } \\
\text { (sss) }\end{array}$ \\
\hline Weight $[\mathrm{Kg}]$ & 378 & 213 & 898 & 1347 \\
\hline
\end{tabular}

\begin{tabular}{|c|c|c|}
\hline Energy & Consumption & Unit \\
\hline Fossil fuel & 2637.48 & MJ \\
\hline Electricity & 567,2 & MJ \\
\hline Raw materials & Consumption & Unit \\
\hline Cement & 378000 & $\mathrm{~g}$ \\
\hline Sand & 898000 & $\mathrm{~g}$ \\
\hline Stone & 1347000 & $\mathrm{~g}$ \\
\hline Wáter & 226880 & $\mathrm{~g}$ \\
\hline Emissions & Fugitive emissions & Unit \\
\hline Carbon dioxide $\left(\mathrm{CO}_{2}\right)$ & 340320 & $\mathrm{~g}$ \\
\hline Nitrogen oxide $\left(\mathrm{NO}_{x}\right)$ & 1559,8 & $\mathrm{~g}$ \\
\hline Sulfur Oxide $\left(\mathrm{SO}_{2}\right)$ & 397,04 & $\mathrm{~g}$ \\
\hline Methane $\left(\mathrm{CH}_{4}\right)$ & 368,68 & $\mathrm{~g}$ \\
\hline $\begin{array}{l}\text { Volatile organic constituent } \\
\text { (COV) }\end{array}$ & 510,48 & $\mathrm{~g}$ \\
\hline Dust & 65,23 & $\mathrm{~g}$ \\
\hline $\begin{array}{l}\text { Heavy } \\
(\mathrm{Cr}, \mathrm{As}, \mathrm{Cd}, \mathrm{Hg}, \mathrm{Tl}, \mathrm{Pb})\end{array}$ & 56720 & $\mu \mathrm{g}$ \\
\hline
\end{tabular}

As a conclusion of this study it is underlined, as regards the energy used, that the highest consumption comes from fossil fuel. It should be taken into account that when the steamgenerated power is used (coal), the footprint increases outstandingly while it decreases when the water electricity is used. This denotes the importance of the choice of the energy to be used when the service is generated or a product is made. As regards the direct emissions it has been kept in mind the elimination of $\mathrm{CO}_{2}$ coming from the decarbonation of limestone during cooking time in the clinker (oven) smelting furnace. As regards the materials, it can be considered that they are the most influential part of the total track being of 9 ha/ inhabitant/year. Mainly, it should be considered the volume of the clinker that is used, together with the fact that it has a big intrinsic footprint; this means that it is precisely the starting materials that need a deeper analysis to diminish the EF of the concrete (Sánchez et al., 2012).

\section{Methodology}

Taking into account the references cited, it was proposed as the main objective, to elaborate the concrete as a substitute of the coarse aggregate by a multilayer plastic (pp, opp and pvc) coming from CRESE ( Enterprise of the recollection of waste in the city of Córdoba) Its mechanical and thermal properties were evaluated and in that way developing criteria for its design and application.

In this way, it is tied to generate an alternative for the reduction of the EF of the conventional concrete and compare it with the EF of the concrete at worldwide level. It is proposed as specific objectives: To analyze and select with technological criteria the recycled plastic materials / To develop dosage for fine sustainable concrete that incorporates aggregates coming from plastic waste / To characterize physically, mechanically and thermally the mixture of lightweight sustainable concrete with plastic waste

\section{Experimental plan}

Now the stages to attain the objectives mentioned before are defined: Description of the materials / Design of the concrete / Analysis of the performance of concrete with some plastic / Analysis of the performance of concrete with plastic waste in hardened state / Study of the thermic conductivity of concrete with plastic waste.

\section{Characterization of the materials}

Cement: normal cement was used and it was characterized as CPN40, according to IRAM 50.000. Relative density: 3,15. Additive: the additive used is a hyper free flowing of the last generation based on other polycarboxilate. Its solid waste is $36,2 \%$. Multilayer plastic: the plastic material was classified to know the physical characteristics such relative density and granule meter. In Figure 1 we can see its appearance. Physical properties of the multilayer plastic ( $p p$, opp y pvc): Relative density: $0.83 \mathrm{~kg} / \mathrm{dm}^{3}$, Fineness modulus: 6.18

Coarse aggregate: it was used as a coarse aggregate a crushing stone of normal use in the area whose physical characteristics 
are presented below and the granulometric curve in figure 2 . Physical properties of coarse aggregate: Máximum size: $19 \mathrm{~mm}$, Relative Density: $2,78 \mathrm{~kg} / \mathrm{dm}^{3}$, Absorption: 0,75\%.

Fine aggregate: we used a mixture of natural sands (fine and coarse) to get a constant granulometric under borderline curves, according to current norms of IRAM 1627 (1997). In the following paragraph the physical characteristics of the mixed sand are presented in Figure 3 its granulometric curve. Physical properties of fine aggregate: Fineness modulus: 3,11, Relative density: $2,63 \mathrm{~kg} / \mathrm{dm}^{3}$, Absorption: 0,9\%.
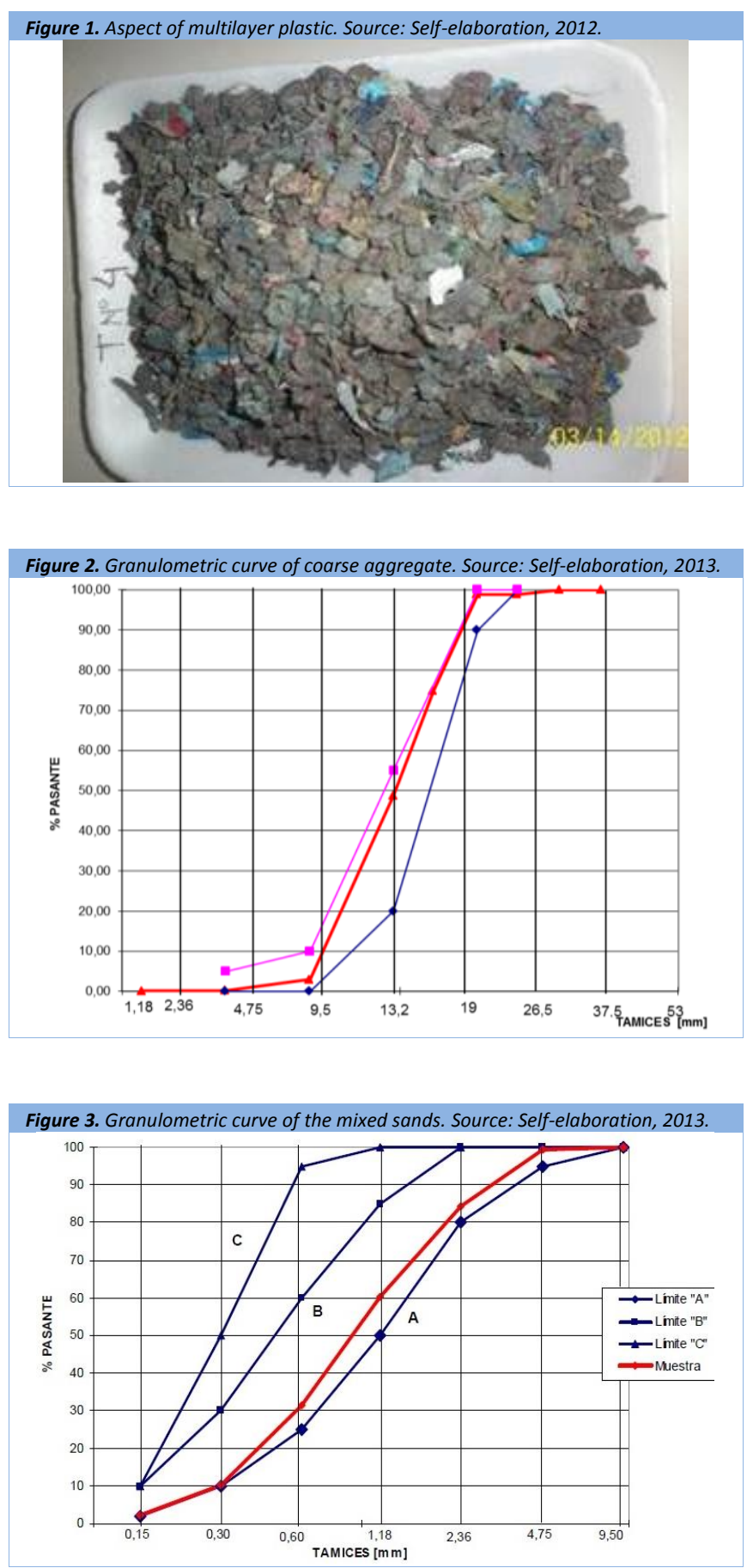

\section{Concrete design}

Once the materials to be used in the mixture were characterized, three groups of concrete were designed: patterned concrete of reference without plastic; a concrete with a replacement of $10 \%$ of the volume of coarse aggregate for multilayer plastic and the other with a replacement of $20 \%$. In Table 3 different dosages are presented and their denomination is the following: $\mathrm{HP}_{0}$, Patterned concrete without multilayer plastic. $\mathrm{HPN}_{30}$, with $30 \mathrm{~kg}$ of plastic per $\mathrm{m}^{3}$ of concrete ( $10 \%$ in volume of coarse aggregate). $\mathrm{HPN}_{58}$, with 58 $\mathrm{kg}$ of plastic per $\mathrm{m}^{3}$ of concrete $(20 \%$ in volume of coarse aggregate).

Table 3. Dosage for one $m^{3}$ of concrete for a relation $a / c=0,54$. Source: Selfelaboration, 2013.

\begin{tabular}{l|l|l|l}
\hline Material [Kg] & $\mathbf{H P}_{\mathbf{0}}$ & $\mathbf{H P N}_{\mathbf{3 0}}$ & $\mathbf{H P N}_{\mathbf{5 8}}$ \\
\hline Cement & 350 & 350 & 350 \\
\hline Water & 190 & 190 & 190 \\
\hline Fine aggregate 1 (sss) & 735 & 735 & 735 \\
\hline Fine aggregate 2 (sss) & 184 & 184 & 184 \\
\hline Coarse aggregate (sss) & 971 & 874 & 777 \\
\hline Plastic & ---- & 30 & 58 \\
\hline Aggregate & 1,75 & 1,75 & 1,75 \\
\hline
\end{tabular}

Table 4. Quantity of materials used in the production of a conventional concrete per inhabitant in 2011 at worldwide level. Source: Self-elaboration, 2013.

\begin{tabular}{l|l|l|l|l}
\hline & Cement & Water & $\begin{array}{l}\text { Fine } \\
\text { aggregate } \\
\text { (sss) }\end{array}$ & $\begin{array}{l}\text { Coarse } \\
\text { aggregate (sss) }\end{array}$ \\
\hline Material Kg & 480 & 270 & 1140 & 1710 \\
\hline
\end{tabular}

able 5. Environmental profile of the concrete per inhabitant/year at worldwide level. Source: Self-elaboration, 2013.

\begin{tabular}{l|l|l}
\hline level. Source: Self-elaboration, 2013. & Consumption & Unit \\
\hline Energy & 3348 & $\mathrm{MJ}$ \\
\hline Electricity & 720 & $\mathrm{MJ}$ \\
\hline Raw materials & Consumption & Unit \\
\hline Cement & 480000 & $\mathrm{~g}$ \\
\hline Fine sand & 1140000 & $\mathrm{~g}$ \\
\hline stone & 1710000 & $\mathrm{~g}$ \\
\hline Water & 270000 & $\mathrm{~g}$ \\
\hline Emissions & Fugitive Emissions & $\mathrm{Unit}$ \\
\hline Carbon dioxide $\left(\mathrm{CO}_{2}\right)$ & 432000 & $\mathrm{~g}$ \\
\hline Nitrogen oxide $\left(\mathrm{NOx}^{2}\right)$ & 1980 & $\mathrm{~g}$ \\
\hline Sulfur Dióxide $\left(\mathrm{SO}_{2}\right)$ & 504 & $\mathrm{~g}$ \\
\hline Methane $\left(\mathrm{CH}_{4}\right)$ & 468 & $\mathrm{~g}$ \\
\hline $\begin{array}{l}\text { Volatile organic components } \\
\text { (COVtot) } \\
\text { Dust }\end{array}$ & 648 & $\mathrm{~g}$ \\
\hline $\begin{array}{l}\text { Heavy } \\
\left.\text { (Cr,As,Cd, } \mathrm{Hg}_{\mathrm{Tl}}\right)\end{array}$ & 82,8 & $\mathrm{~g})$ \\
\hline
\end{tabular}


Calculation of the ecological footprint of a worldwide conventional concrete

According to some studies done by ACC Limited (2012), the consumption of cement per capita at a worldwide level in 2011 was $480 \mathrm{~kg} /$ inhabitant/year. From this datum, and taking into account the dosage for a conventional concrete, it is estimated that the quantity of concrete consumed in $\mathrm{kg}$ by a person in 2011 is of $3600 \mathrm{~kg}$ equivalent to the consumption of $1,5 \mathrm{~m}^{3}$ of the dosage of conventional concrete. In Table 4 the quantity of materials used in the production of this concrete can be observed.

- Quantity of materials released into the atmosphere during the production of conventional concrete at worldwide level. According to the quantity of concrete consumed by a person in 2011 we obtain the consumption of energy, raw materials and emissions that are generated in its production and that are presented in Table 5.

- Direct emissions: calculation of the carbon footprint of the fuels. 1) Obtaining of the tons/year of used fuel: Fossil fuel 3348 $\mathrm{MJ}=3.34 \mathrm{GJ} . / 2$ ) Obtaining of the total gigajoules: Electricity $720 \mathrm{MJ}=0.72 \mathrm{GJ}$. / 3) Obtaining of the carbon footprint from the fugitive emissions and others: Carbon dioxide $\left(\mathrm{CO}_{2}\right): 0,432000$ Tn/inhabitant/year, Nitrogen oxide $\left(\mathrm{NO}_{\mathrm{x}}\right)$ : 0,001980 $\mathrm{Tn} /$ inhab/year, Methane $\left(\mathrm{CH}_{4}\right): 0,000468 \mathrm{Tn} /$ inhabitant/year, Volatile organic components (VOC tot): 0,000648 Tn/inhabitant/year, Dust: 0,0000828 Tn/inhabitant/year, Heavy metals $(\mathrm{Cr}, \mathrm{As}, \mathrm{Cd}, \mathrm{Hg}, \mathrm{Tl}, \mathrm{Pb})=0.072, \mathrm{~g}=0.000072$ Tn/inhabitant/year. /4) Calculation of the footprint of the materials: they consist of those raw materials that shops buy to sell to a third party, they are flow materials because they are bought to a supplier with certain footprint. With the footprint of the materials, an important group of sources of emissions of $\mathrm{CO}_{2}$ that are those considered as "other indirect emissions" by the most well-known international standards. The steps to follow to calculate the footprint of the materials are the following: Fine aggregate $1140 \mathrm{~kg}+$ coarse aggregate $1710 \mathrm{~kg}=$ $2.85 \mathrm{Tn}$, Cement $480 \mathrm{~kg}=0.48 \mathrm{Tn}$. / 5) Calculation of the water consumption. Water: $270 \mathrm{~kg}=0.27 \mathrm{Tn}$. For the application of the methodology, it will be necessary to introduce the inputs in the correct cells of the worksheet (first column) in this way reaching the outputs automatically in the last two columns.

- Conversion from carbon footprint to ecological footprint. Finally, all the reached carbon footprint is converted to ecological footprint (that is to say, $\mathrm{CO}_{2}$ to hectares) dividing the first by the absorption factor of the considered ecosystem ("woods for $\mathrm{CO}_{2}$ ") and whose result can be observed in Figure 4. In the case of direct emissions, the great percentage is obtained from the fuel emissions, being the emissions of other gases minimal.

As regards the water energy used, the footprint is null; however when thermic energy is used (carbon- fuel) the footprint increases in a considerable way. This shows the importance of the choice of the energy to be used in the generation of a service or the making of a product. It is convenient to clarify that, for the calculation of the ecological footprint at worldwide level, we start from the supposition that the consumptions are homogeneous, which is not true, at least if we consider and contrast the average consumptions of the inhabitants of the developed countries with the consumptions per capita of the Third World countries.

\section{Analysis of the Results}

- Performance of the concrete with a plastic waste in a fresh state. With the objective of verifying the influence of plastic in the management of the concrete, some trials were done in fresh state determining the Abrams' conic settlement, according to IRAM 1536 (1978) standards. The results obtained are presented below and in Figure 5. Results of Settlement: $\mathrm{HP}_{0}:: 5,0 \mathrm{~cm} / \mathrm{HPN}_{30}: 3,0 \mathrm{~cm} / \mathrm{HPN}_{58:}: 2,0 \mathrm{~cm}$. The settlement of the concrete with the addition of plastic is lower than the patterned concrete and it diminishes as the plastic percentage increases, in that way keeping cohesion.

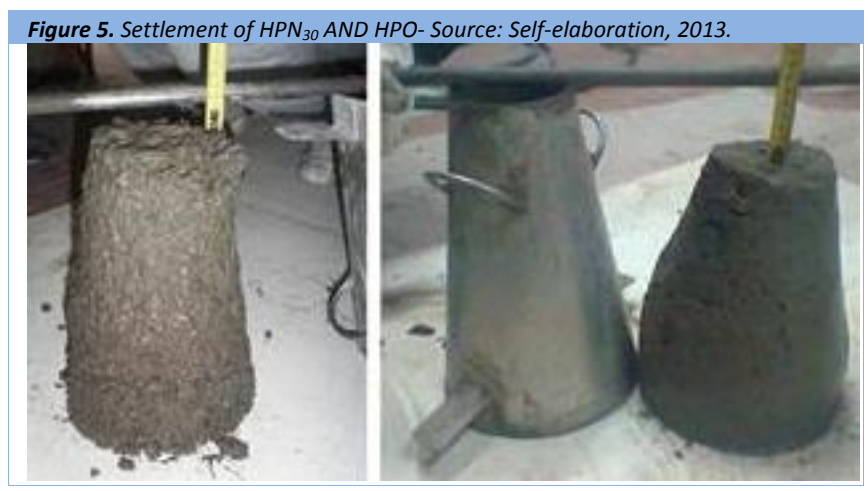

\begin{tabular}{|c|c|c|c|}
\hline Ages & $\mathrm{HP}_{0}[\mathrm{MPa}]$ & $\mathrm{HPN}_{30}[\mathrm{MPa}]$ & $\mathrm{HPN}_{58}[\mathrm{MPa}]$ \\
\hline 7 days & 25,8 & 21,9 & 21,9 \\
\hline 28 days & 32,2 & 27,2 & 24,15 \\
\hline 90 days & 40,4 & 33,4 & 28,7 \\
\hline Density kg/m³] & 2431 & 2363 & 2294 \\
\hline
\end{tabular}

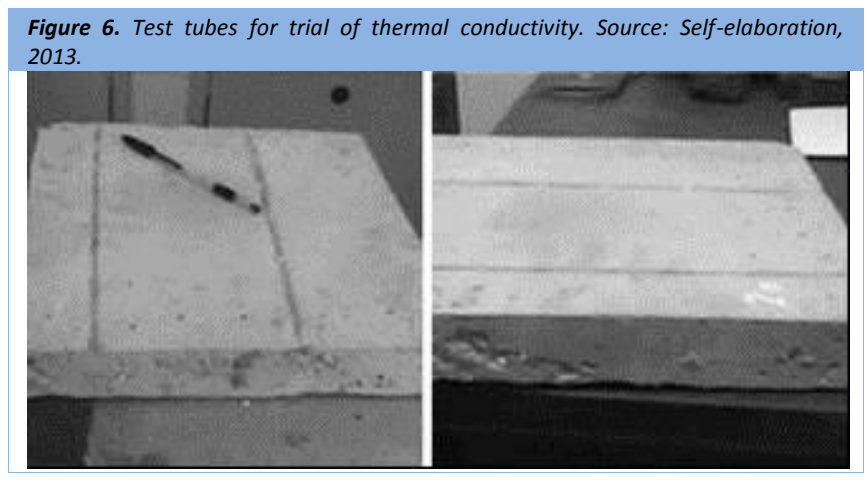

- Performance of concretes with plastic waste in hardened state. Good results were obtained in hardened state at compression at ages of 7 and 28 days with the HPN. The values reached are presented in Table 6. 
At 7 days of age the resistance to compression presents reductions of an order of $15 \%$ in the concrete with plastic. At 28 and 90 days of age, the difference of the resistance to compression between the patterned concrete and the concrete with the addition of $20 \%$ of plastic is significant. However, the results conform the resistance to the minimal compression required for a light concrete to be used with structural objectives, according to $\mathrm{ACl} 318 \mathrm{~S}$ (2008).

- Thermic conductivity of concrete with plastic waste. To analyse the thermic performance of the concrete, the coefficient of thermic conductivity was determined by means of an equipment of hot plate, according to IRAM regulation 11.559 (determination of the thermic resistance and related properties in a steady state. (Method of the hot plate) whose test tubes are shown in Figure 6. These determinations were done in the Department of Thermodynamic in the National University of the Northeast, reaching encouraging results that are presented below. Results of Thermal Conductivity $(\lambda): \mathrm{HP}_{0}: 1,4 \mathrm{~W} / \mathrm{m} \stackrel{\mathrm{oK}}{ }$,

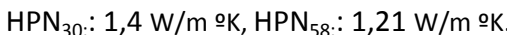

- Analysis of the ecological footprint of concrete with plastic waste. Once verified the performance in fresh and hardened state of the concrete with plastic and therefore the preliminary feasibility of use of these wastes in the construction industry, the calculation of EF of these concrete were done and it was compared with the conventional concrete at worldwide level. In figure 7 we can observe the EF of the conventional concrete at worldwide level and in Figure 8 we can observe a decrease of $10 \%$ of the EF of concrete with replacement of the coarse aggregate by multilayer plastic as regards the conventional concrete at worldwide level. The EF of the concrete with plastic is 9.8 he/inhabitant/year.

The aggregates occupy the biggest volume in the elaboration of the concrete but they have an environmental load small in proportion to the EF of the total of the materials that are used, affecting only the $8 \%$. This is due to the liberation rates of $\mathrm{CO} 2$ more significant in the total footprint of the concrete correspond mainly to the content of the cement. For this reason some options to implement in order to reduce the EF of the concrete are to work with CPC (Compound Portland Cement) and besides incorporates to the mixture mineal aggregates to replace the cement.

The use of recycled plastic waste as a replacement of the coarse aggregate in the concrete contributes to some environmental benefits around two ways. On the one hand, it avoids the need to obtain, produce or explote natural materials (with the correspondent environmental impact that this implies) while it gives a solution to the pour of waste material. Also due to the low cost of these wastes, the obtained result can be even more economical than the coming from the natural aggregates.
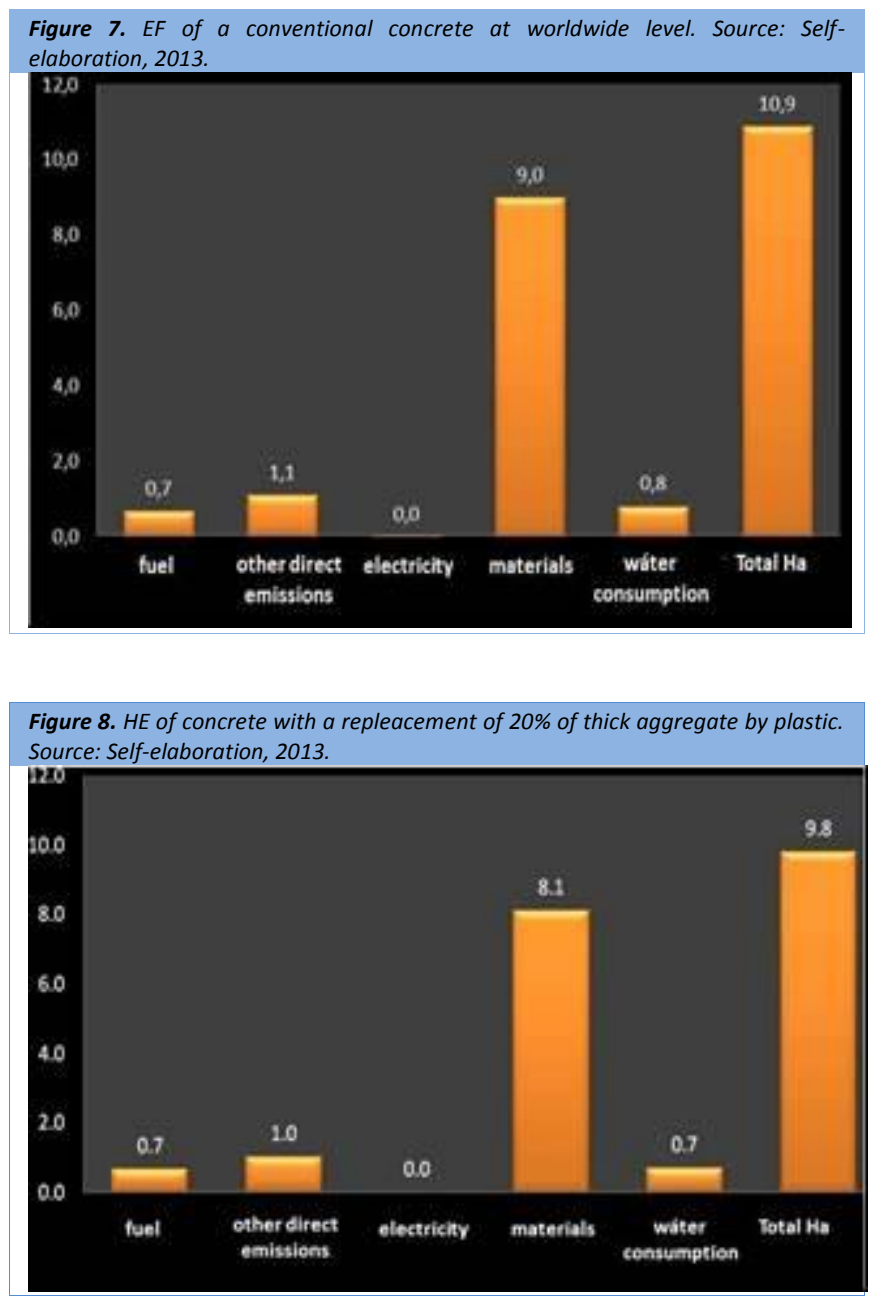

Conclusions

The results obtained in fresh and hardened state allow us to estimate that the plastic aggregates are adequate to be used in the construction industry. In fresh state they show that, although the irregular and angular shape of the multilayer plastic makes it difficult to work with the concrete decreasing its settlement, it is possible to obtain a good cohesion of the particles and to use this mixture in the elaboration of prefabricated objects. The reduction of the settlement can be compensated with an increase of water and cement. Although this would increase its cost, it should have to be evaluated in the context of the sustainability of the environment.

In hardened state, the resistance decreases as the percentage of the incorporation of plastic waste increases. However, the results are good in comparison with the minimum resistance demanded for a structural light concrete, allowing us to have a menu of bearing and non-bearing plates. The results of the study of the thermal conductivity are encouraging because the conductivity of the concretes decreases as a higher percentage of plastic is incorporated. It allows the reduction of the thickness of the walls, and consequently it consumes less concrete due to the efficient energetic performance of the material thus contributing to have more comfortable spaces from a thermal point of view. 
This case of study presents a tool that opens a possibility to know the most sustainable option in the stage of the design of the project; once the data of investment and the exploitation costs are known, it is possible to design different options of concrete calculating the ecological footprint and analyzing which one will have the less environmental impact. It is possible to try out different materials with the objective of finding out which ones will give the most eco efficiency.

We will continue with the research, studying the incorporation of multilayer plastic of the concrete, going deeper in the dosage analysis, the mechanic and durability characteristic and especially, the properties of thermal conductivity in order to verify the insulating capacity. Finally, we will analyse the advantages and the weak points, planning corrective measures to contribute to sustainability, reducing the EF of the concrete in Córdoba, Argentina.

\section{Acknowledgements}

We are very grateful to CINTEMAC Center of Investigation, Development and Transference in Materials and Quality of the National Technologic University. Regional Faculty of Córdoba to provide us with the physical space and the research background and to CONICET for the doctoral scholarship.
References

ABNT NBR ISO 14.040. (2009). Associação Brasileira de Normas Técnicas. Avaliação do ciclo de vida, princípios e estrutura. Rio de Janeiro, Brasil.

ACC Limited. (2012). Motilal Oswal Investor Conference. India.

ACl 318M-08 (2008). American Concrete Institute. Building Code Requirements for Structural Concrete and Commentary. American Concrete Institute: Michigan, United States.

Aline de Oliveira, S., Dziedzic, M., \& Sato Daher, C. (2011). Análise do Ciclo de Vida, do Berço ao Transporte, do Concreto Usinado Destinado à Confecção de Estruturas de Edificações de Curitiba-PR. 53o Congresso Brasileiro do Concreto in Florianópolis, Brasil.

Calkins, M. (2008). Materials for Sustainable Sites: A Complete Guide to the Evaluation, Selection, and Use of Sustainable Construction Materials. California, USA.

Chambers, N; Simmons, C and Wackernagel, M (2000). Sharing Nature's Interest: Ecological Footprints as an Indicator of Sustainability. London: Earthscan.

Doménech, J. L. (2007). Huella ecológica y desarrollo sostenible. AENOR. Asociación española de normalización y certificación. Madrid, España.

Freitas, J., Parchen, C., \& Rodrigues Parchen, M. F. (2010). Importância do concreto na geração de $\mathrm{CO}^{2}$ em um caso de obra de um edifício. 52을 Congresso Brasileiro do Concreto. Centro Politécnico - Jd. das Américas. Curitiba, Brasil.

Häkkinen, T. and Vares, S. (1998). Environmental Burdens of concrete and concrete products, Technical Research Centre of Finland.

IRAM 1627 (1997). Instituto Argentino de Normalización y Certificación. Granulometría de los agregados para hormigón. Buenos Aires, Argentina.

IRAM 1536 (1978). Instituto Argentino de Normalización y Certificación. Hormigón Fresco de Cemento Portland. Método de Ensayo de la Consistencia utilizando el tronco de cono. Buenos Aires, Argentina.

IRAM 11559 (1995). Instituto Argentino de Normalización y Certificación. Acondicionamiento térmico. Determinación de la resistencia térmica y propiedades conexas en régimen estacionario. Método de la placa caliente con guarda. Buenos Aires, Argentina.

Jain, R. K.; Urban, L. V. and Stacey, G. S. (1977). Environmental Impact Analysis: a new dimension in decision making. New York: Van Nostrand Reinhold. ISBN 0442288077

La Mañana de Córdoba (2011). Medios del interior S. A. Córdoba. República Argentina.

Sánchez, S., Oshiro A., \& Positieri M. (2012). Cálculo de la huella ecológica del hormigón. AATH. Asociación Argentina de Tecnología del Hormigón. Buenos Aires, Argentina.

Simmons, C., Lewis, K., \& Barratt, J. (2000). Two feet-two approaches: a component-based model of Ecological Footprinting. Ecological Economics 32(3) 375-380.

Wackernagel, M. and Rees, W. (2001). Nuestra Huella Ecológica. Reduciendo el Impacto Humano sobre la Tierra. Ediciones LOM/Instituto de Ecología Politica: Santiago de Chile.

WasteOnline (http://www.wasteonline.org.uk). [Visited 12.03.12] 


\section{ECOLOGICAL FOOTPRINT OF THE CONCRETE 2013 DATA ENTRY}

\begin{tabular}{|c|c|c|c|c|c|c|c|c|c|}
\hline \multirow[t]{2}{*}{ CATEGORIES } & \multirow[b]{2}{*}{\begin{tabular}{|c|} 
in \\
tons \\
[t/year]
\end{tabular}} & \multirow[b]{2}{*}{\begin{tabular}{|c|} 
In \\
gigajoules \\
[Gj/year] \\
\end{tabular}} & \multicolumn{2}{|c|}{ Conversion factors } & \multicolumn{3}{|c|}{\begin{tabular}{|c|} 
Footprint by type of \\
ecosystem(in hectares)
\end{tabular}} & \multirow{2}{*}{$\begin{array}{c}\begin{array}{c}\text { Total } \\
\text { footprint }\end{array} \\
\text { [ha] }\end{array}$} & \multirow{2}{*}{$\begin{array}{l}\text { Riser } \\
\text { [ha] }\end{array}$} \\
\hline & & & $\begin{array}{c}\text { Natural } \\
\text { productivity } \\
\text { [t ha/year] }\end{array}$ & \begin{tabular}{|l|} 
Productiv. \\
energética \\
[Gj/ha/año] \\
\end{tabular} & $\begin{array}{c}\text { Wood } \\
\mathrm{CO}_{2} \\
{[\mathrm{ha}]}\end{array}$ & $\begin{array}{c}\text { Grass } \\
\text { [ha] }\end{array}$ & \begin{tabular}{|c|} 
Woods \\
[ha]
\end{tabular} & & \\
\hline \multicolumn{10}{|l|}{ 1. Direct emissions } \\
\hline \multicolumn{10}{|l|}{1.1 fuels } \\
\hline Coal (anthracite) (Combustion) & & & & & & & & 0,0 & \\
\hline " (Life cycle) & & & & & & & & 0,0 & \\
\hline Firewood & & & & & & & & 0,0 & 0,0 \\
\hline (Life cycle) & & & & & & & & 0,0 & \\
\hline Wood biomass & & & & & & & & 0,0 & 0,0 \\
\hline (Life cycle) & & & & & & & & 0,0 & \\
\hline Natural gas & & & & & & & & 0,0 & \\
\hline (Life cycle) & & & & & & & & 0,0 & \\
\hline Fuel & & 3,35 & & & 0,7 & & & 0,7 & \\
\hline (Life cycle) & & & & & & & & 0,0 & \\
\hline Subtotal 1.1 & & & & & 0,7 & 0,0 & 0,0 & 0,7 & \\
\hline \multicolumn{10}{|l|}{1.2 other direct emissions } \\
\hline Fugitive emissions $1\left(\mathrm{CO}_{2}\right)$ & 0,432 & & & & 0,432 & & & & \\
\hline Fugitive emissions $2\left(\mathrm{NO}_{\mathrm{x}}\right)$ & 0,00198 & & & & 0,002 & & & & \\
\hline Fugitive emissions $3\left(\mathrm{SO}_{2}\right)$ & 0,0005 & & & & 0,0005 & & & & \\
\hline Fugitive emissions $4\left(\mathrm{CH}_{4}\right)$ & 0,00047 & & & & 0,0005 & & & & \\
\hline Fugitive emissions 5 (COVtot) & 0,00065 & & & & 0,0006 & & & & \\
\hline Fugitive emissions 6 Dust & $8,3 E-05$ & & & & $8 \mathrm{E}-05$ & & & & \\
\hline Fugitive emissions $7(\mathrm{Cr}, \mathrm{As}, \mathrm{Cd}, \mathrm{Hg}, \mathrm{Tl}, \mathrm{Pb})$ & $7,2 \mathrm{E}-05$ & & & & $7 \mathrm{E}-05$ & & & & \\
\hline \begin{tabular}{|c|} 
Subtotal 1.2 \\
\end{tabular} & & & & & 0,4 & 0,0 & 0,0 & 0,4 & \\
\hline Total 1 & & & & & 1,1 & 0,0 & 0,0 & 1,1 & \\
\hline \multicolumn{10}{|l|}{ 2. Indirect Emissions } \\
\hline \multicolumn{10}{|l|}{ 2.1 Electricity } \\
\hline Thermic (coal- fuel) & & & & & & & & 0,0 & \\
\hline " (life cycle) & & & & & & & & 0,0 & \\
\hline Gas thermic (combined cycle) & & & & & & & & 0,0 & \\
\hline (life cycle) & & & & & & & & 0,0 & \\
\hline Nuclear (combustion) & & & & & & & & 0,0 & \\
\hline (life cycle) & & & & & & & & 0,0 & \\
\hline Hydraulic & & 0,72 & & 15000,0 & & 0,0 & & 0,0 & \\
\hline (life cycle) & & & & & & & & 0,0 & \\
\hline Subtotal 2.1 & & & & & 0,0 & 0,0 & 0,0 & 0,0 & \\
\hline Total 2 & & & & & 0,0 & 0,0 & 0,0 & 0,0 & \\
\hline \multicolumn{10}{|l|}{ "Other indirect emissions" } \\
\hline \multicolumn{10}{|l|}{ 3.- Inorganic materials } \\
\hline \multicolumn{10}{|l|}{ 3.1 Flow materials (goods without VAT) } \\
\hline Raw materials (aggregates, min & $2.85 \mathrm{Tn}$ & & & & 0,7 & & & 0,7 & \\
\hline Cement & $0.48 \mathrm{Tn}$ & & & & 8,3 & & & 8,3 & \\
\hline Bricks, Ceramic and refra materi & & & & & & & & 0,0 & \\
\hline Glass derivatives & & & & & & & & 0,0 & \\
\hline Porcelain material and toilet & & & & & & & & 0,0 & \\
\hline Total 3 & & & & & 9,0 & 0,0 & 0,0 & 9,0 & \\
\hline 4. Water & & & [m³/ha/año] & & & & & & \\
\hline \multicolumn{10}{|l|}{ Drinking water consumption } \\
\hline Anti-dust irrigation (in bulks) & 0,27 & & 1.500 & & & & 0,7 & 0,7 & \\
\hline Industrial processes & & & & & & & & 0,0 & \\
\hline Total 4 & & & & & 0,0 & 0,0 & 0,7 & 0,7 & \\
\hline TOTAL ha & & & & & 1,1 & & 0,7 & 10,9 & \\
\hline & & & & & & & & & 10,9 \\
\hline
\end{tabular}

